Andrzej Józef MADERA

Akademia Pedagogiczna w Krakowie

\title{
Fenomen „Gazety Wyborczej”
}

a fenomen „Gazety Wyborczej” składa się wiele czynników. Dzieje
"Gazety” dokumentują niezwykłą historie o tym, jak grupa ludzi, natrafiając na wyjątkową i niepowtarzalną chwilę w polskich dziejach i korzystając ze społecznego poparcia udzielonego „Solidarności” wiosną 1989 roku, stworzyła najpopularniejszy w kraju dziennik.

Prawie 14 lat temu w założeniu pomysłodawców „Gazeta Wyborcza” miała do spełnienia ściśle określoną rolę polityczną - pomóc „Solidarności” w przejęciu władzy i w dniu wyborów przestać się ukazywać. Jednak stało się inaczej. W ciągu kilku miesięcy 1989 roku stała się największym i najbardziej opiniotwórczym dziennikiem. Adam Michnik wspominał kiedyś, że „przy »okragłym stole« zbiegły się dwie sprawy. Myśmy wydyskutowali, że przy wyborach będzie pismo w rodzaju wyborczej jednodniówki. A oprócz tego miał powstać niezależny dziennik związany ze stroną opozycyjną »okrągłego stołu «. Z taką myślą została powołana grupa ludzi mająca redagować gazetę. Kadry zaczerpnęliśmy z solidarnościowego podziemia. Było to pospolite ruszenie. Ogłosiliśmy apel do ludzi w jakiś sposób związanych z opozycją. Od razu udało nam się wystartować jako dziennik, a nie jednodniówka. »Gazeta Wyborcza« miała funkcjonować do wyborów, ale w tym zamieszaniu politycznym zapomniano o nas. Zachowaliśmy ciagłość. Nikt nie odebrał nam dziennika"l.

To pierwszy fenomen „Gazety Wyborczej”, o którym dzisiaj mało kto pamięta. Z drugiej strony, dla wielu ludzi szczególny czas historyczny, w którym powstała „Gazeta”, w znaczący sposób zadecydował o jej sukcesie. Twierdzą, że każdy dziennik, który powstałby na tych samych zasadach co „Wyborcza”, prawdopodobnie odniósłby taki sam sukces. Trudno nie zgodzić się z tezą, że czynnik historyczny był dominujący. Niestety, jest to twierdzenie niesprawdzalne doświadczalnie, gdyż tylko „Gazeta”

${ }^{1}$ L. Dzierba, Geneza i rozwój „, Gazety Wyborczej” - firmy XXI wieku, w: Świat i Polska końca XX wieku, pod red. M. Żmigrodzkiego, Lublin 1996. 
powstała w tym czasie. Jednak o kształcie „Gazety”, o zawartości i sposobie zdobywania rynku decydowali konkretni ludzie. To oni nadali „Gazecie" taki a nie inny profil, który spowodował sukces na rynku prasowym. Prawdopodobnie, gdyby „Wyborcza” przyjęła inną linię programową, szczególnie polityczną, nie zdobyłaby tylu czytelników. Dowodem na to jest los „Życia”, którego redaktorem naczelnym był Tomasz Wołek.

Fenomenem „Gazety” jest też fakt, że stworzyli ją ,amatorzy”, którzy nie byli dziennikarzami, redaktorami, drukarzami czy specjalistami od reklamy prasowej. Nie można bowiem nazwać doświadczeniem wydawania podziemnego pisma, o niskiej jakości technicznej, dotowanego przez „Solidarność". Pisma te często miały niewiele wspólnego z rzetelną informacją, pełniły raczej rolę czysto polityczną. $\mathrm{Ci}$ sami ludzie, w ciągu kilku miesięcy, musieli przestać agitować, a zaczać informować. Szybko zrozumieli też, że bez czytelników „Gazeta” nie przetrwa. Stworzyli więc dziennik świetnie redagowany, który dostarcza czytelnikom treści na różnych poziomach i według różnych potrzeb.

„Gazeta Wyborcza” od kilku lat przewodzi niezmiennie w rankingach czytelniczych. Każdego dnia rano setki tysięcy ludzi idzie do kiosków, żeby ją kupić. W 1989 roku towarzyszyły temu wielkie emocje: pod kioskami ustawiały się kolejki, zdobywało się ostatnie egzemplarze „spod lady”, a ci, którzy mieli mniej szczęścia, pożyczali ją od sąsiadów „na godzinę". Pierwszy raz od lat czytano gazetę z wypiekami na twarzy: o czym dziś napiszą, co się wydarzyło, jaka jest prawda. „Gazeta” była dla wielu Polaków namacalnym znakiem zmian zachodzących w kraju. Opisywała tematy zakazane i pokazywała, że zamiast nowomowy można używać prostego, żywego i zrozumiałego języka, w którym „tak” znaczy „tak”, a „nie” znaczy „nie”.

Sytuacja społeczno-polityczna Polski w okresie transformacji jest jednocześnie kawałkiem historii „Gazety Wyborczej”. Bez „okrągłego stołu” nie byłoby „Gazety”. Być może, bez „Gazety” nie byłoby wygranych przez opozycję wyborów. Nie byłoby polskiej demokracji. „Gazeta Wyborcza" powstała w określonym czasie i miejscu, dlatego analizując jej powstanie, nie należy pomijać kontekstu historycznego.

Dziś, po czternastu latach istnienia „Gazety Wyborczej”, dla setek tysięcy ludzi sięgnięcie po nią stało się nawykiem, rutynową poranną czynnością. Mniej jest także emocji w samej gazecie, która w oczywisty sposób dojrzewa wraz z polską demokracją. „Gazeta” jest dzisiaj najpopularniejszym dziennikiem o zasięgu ogólnopolskim. Jest także dynamiczną instytucją, zatrudniającą ok. 2800 pracowników, zarządzaną przez 
nowoczesnych i utalentowanych menedżerów. Dysponuje własnymi drukarniami. Jest potentatem na polskim rynku ogłoszeniowym.

"Gazeta" to nie tylko opinia publiczna. „Gazeta” to także dobrze prosperująca firma. Bez pieniędzy przestaje istnieć. Liczba sprzedanych egzemplarzy decyduje o jej bycie, jakości i sile. Dlatego strona ekonomiczna największego polskiego dziennika jest tak ważna. Agora S.A. - wydawca „Gazety Wyborczej” jest obecnie jedną z największych firm akcyjnych w Polsce, a „Gazeta” jest częścią Agory. Bez niej nic nie znaczy. Od osiagnięć finansowych wydawcy zależy jej pozycja i rozwój.

Miliony sprzedanych egzemplarzy, tysiące pracowników, stale rosnąca objętość wydania - to liczby mówiące o skali sukcesu „Gazety”. Pierwszy numer „Wyborczej” liczył zaledwie osiem stron. Już w 1997 r. „Gazeta” miała średnio 100 stron objętości, w Warszawie często przekraczając 200. Dzisiaj średnia dzienna sprzedaż „Wyborczej” utrzymuje się na poziomie ok. pół miliona egzemplarzy; przykładowo - przychody ze sprzedaży „Gazety” za 1999 rok wyniosły 695 milionów złotych, czyli o 26,2 procent więcej niż rok wcześniej.

Opiniotwórczy fenomen „Gazety Wyborczej” jest nierozerwalnie związany z siłą wydawniczą i czytelniczo-autorską dziennika. Bez jednego elementu rozpada się całość. Gdyby nie dziennikarze, nie byłoby świetnie zredagowanej, cieszącej się ogromną popularnością „Gazety”. Z kolei liczba sprzedanych egzemplarzy decyduje o miejscu „Gazety” na rynku czytelniczym, a bycie liderem daje ogromną władzę i wpływ na opinię publiczną. Taka władza rodzi też, niestety, pewne zagrożenia, bo z jednej strony „Gazeta” interweniuje w słusznych sprawach, a z drugiej, jak każda instytucja składająca się z omylnych ludzi, może wyrządzać innym krzywdę, którą trudno jest po fakcie sprostować.

„Gazeta Wyborcza” może się podobać lub nie, jednak nikt nie pozostaje obojętny na to, co napisze. O takiej sile marzy każda gazeta, radio czy telewizja. Jest przykładem dziennika aktywnego, którego redaktorzy wierzą, że tylko działaniem można cokolwiek zmienić, nawet jeśli nie wszystko jest możliwe. Jest pomostem pomiędzy społeczeństwem a establishmentem. Na jej łamach ludzie wnoszą rozmaite inicjatywy, które nie pozostają bez echa. Liczne akcje przeprowadzone przez „Gazetę” pokazały, że „Wyborcza” to nie tylko polityka, ale przede wszystkim dziennik przyjazny ludziom. Kampania „Rodzić po ludzku” odmieniła polskie szpitale położnicze, a akcja „Szpital: dom czy więzienie” po raz kolejny udowodniła siłę „Gazety”. Kilkanaście publikacji zmieniło prawo, a przede wszystkim obyczaje panujące w szpitalach. Jeszcze raz słowa okazały 
się mocniejsze niż pieniądze. Właściwie akcje społeczne „Gazety” niczym nie różnią się od tych, które przeprowadzają inne redakcje. Ich niezwykłość polega na tym, że nigdy nie pozostają niezauważone.

Klęska nocy 13 grudnia 1981 roku na długo utemperowała polityczne aspiracje polskiego społeczeństwa. Polacy byli zmęczeni. Z jednej strony beznadzieją polityczną, z drugiej ogromnym trudem codziennego życia. Stan wojenny zamknął przed Polską (i tak zawsze utrudnione) kontakty międzynarodowe. Sankcje gospodarcze Zachodu i nieformalny ostracyzm wobec rządu generała Jaruzelskiego zablokowały rozwój, a doktryna gospodarki sterowanej centralnie zepchnęła kraj w głęboki kryzys ekonomiczny ${ }^{2}$. Podstawowe artykuły żywnościowe (m.in. cukier, mięso, masło) i niektóre przemysłowe (np. buty), a także paliwa samochodowe, były racjonowane i dostępne na kartki. Powszednie trudności potęgowały apatię, a brak perspektyw sensownej pracy (przy odrzuceniu kariery w ramach nomenklatury partyjnej) skłaniał młodych ludzi do myślenia o emigracji. Wielki społeczny zryw roku 1980 wydawał się być stracony ${ }^{3}$.

Pomimo zniesienia stanu wojennego w 1983 roku, liderzy opozycji nadal siedzieli w więzieniach. Wypuszczenie więźniów politycznych było podstawowym warunkiem przywrócenia normalności. Na normalizację nalegały koła kościelne, a także zagraniczni wierzyciele Polski, do których władze PRL zmuszone były odnosić się z coraz większym respektem. Amnestia, spodziewana od roku 1985, ostatecznie została ogłoszona dopiero w połowie września 1986 roku. Na wolność wyszło ponad dwieście osób, między innymi: Władysław Frasyniuk, Bogdan Lis, Zbigniew Bujak, Adam Michnik, Leszek Moczulski ${ }^{4}$. W początkach 1988 roku zaprzestano zagłuszania Radia „Wolna Europa” i „Głos Ameryki”. Zaczęły się kontakty między stroną rządową a przedstawicielami opozycji, np. kół związanych z Kościołem ${ }^{5}$.

„Kiedy generał Kiszczak ogłosił 31 sierpnia 1988 r., że władze proponują opozycji rozmowy przy »okragłym stole«, byłem w Paryżu. - Generał blefuje, to nie może być poważna propozycja - mówiono w kręgu działaczy politycznej emigracji. Kiedy przyjechałem do Krakowa w pierwszych dniach września, zastałem podobne oceny co w Paryżu. [...] Całe

2 A. Wielopolska, Od konfliktu do negocjacji, „Rzeczpospolita”, 5 lutego 1999, nr 30 .

3 Ibidem.

4 Ibidem.

5 Ibidem. 
dotychczasowe doświadczenie PRL nie pozwalało wierzyć w negocjacyjny scenariusz zawarty w ofercie »okragłego stołu«. Ktoś, kto wówczas głosiłby pogląd, że za rok Polska będzie miała niekomunistyczny rząd, uznany byłby za szaleńca” - wspominał na łamach „Gazety” Roman Graczyk $^{6}$.

Politykę władz uwiarygodnić miało powołanie nowego rządu. Premierem został, uchodzący za liberała, wieloletni redaktor naczelny „Polityki” Mieczysław Rakowski. O tym, że Rakowski nie myślał „głaskać” opozycji, świadczyło pozostawienie na stanowisku rzecznika rządu pogardzanego powszechnie Jerzego Urbana. Mocniejszym sygnałem było stwierdzenie premiera, że społeczeństwo woli stół „dobrze zastawiony” niż „okragły”, ale prawdziwym znakiem - zarazem projektowanych zmian gospodarczych, jak przede wszystkim lekceważenia „Solidarności” - była ogłoszona 31 października decyzja o postawieniu w stan likwidacji Stoczni Gdańskiej ${ }^{7}$.

Tym samym Rakowski gwałtownie zahamował toczące się przygotowania do „okragłego stołu”. Ich wznowienie było możliwe tylko dzięki mediacji Kościoła. Rozmowy szły tak opornie, że nawet rozebrano specjalnie zbudowany i ustawiony w pałacu w Jabłonnie olbrzymi okragły stół, przy którym miały się toczyć obrady plenarne. Punktem spornym stał się skład „solidarnościowej” reprezentacji. Kiszczak gotów był rozmawiać z każdym, tylko nie z Michnikiem i Kuroniem ${ }^{8}$.

W grudniu 1988 r., przy Lechu Wałęsie, jako przewodniczącym NSZZ „Solidarność”, ukonstytuował się Komitet Obywatelski, którego sekretarzem został Henryk Wujec. W ramach Komitetu utworzono 15 sekcji tematycznych, w których przygotowywano materiały na potrzeby przyszłych rozmów przy „okragłym stole",

Tymczasem ekipa generała Wojciecha Jaruzelskiego napotkała nieoczekiwany opór ze strony KC PZPR. Dopiero w drugiej części plenum KC, w styczniu 1989 roku, po dwóch dniach burzliwych dyskusji i wobec groźby dymisji Jaruzelskiego, członkowie plenum opowiedzieli się za pluralizmem politycznym i związkowym. Droga do rozmów „okragłego stołu" została otwarta ${ }^{10}$.

6 R. Graczyk, Nasz Wielki Skok, „Gazeta Wyborcza” 5-6 czerwca 1999 r.

A. Paczkowski, Pót wieku dziejów Polski 1939-89, Warszawa 1998, s. 568-569.

J. Kuroń, J. Żakowski, PRL dla poczatkujacych, Wrocław 1999, s. 262.

R. Graczyk, op. cit.

10 Ibidem. 
„Okragły stół” jawił się w świadomości społecznej raczej jako symboliczny koniec epoki bezpośredniej konfrontacji władzy ze społeczeństwem, a zarazem jako jeszcze jedna próba reformy istniejącego systemu, poprzez ograniczone uznanie opozycji. Wszelako zarówno rzeczywiste kierunki, jak i ewentualne granice tego eksperymentu przypominały w dużej mierze skok w nieznane: Polacy byli pionierami; nie mieli żadnego wzoru, do którego mogliby się odnieśćc ${ }^{11}$. Rozmowy przy „okragłym stole” rozpoczęły się 6 lutego 1989 roku i trwały do 5 kwietnia, a zawarte porozumienie umożliwiało powrót na scenę polityczną „Solidarności”.

„Przy okragłym stole usiedli naprzeciw siebie ludzie, których dzieliło wszystko. Nie znali się, nie szanowali, nie ufali sobie. I do tego szczerze się nie znosili. A przecież dla jednych i drugich był to moment egzaminu nie bójmy się wielkich słów - z patriotyzmu i odpowiedzialności za Polskę" - pisał dziesięć lat później Adam Michnik ${ }^{12}$.

Pierwszy numer „Gazety Wyborczej” ukazał się w poniedziałek, 8 maja 1989 roku. Miał osiem stron i kosztował 50 złotych. Z pierwszej strony do czytelników uśmiechał się Lech Wałęsa. Redakcja informowała, że „oto, po z górą czterdziestu latach powstaje pierwszy w Polsce, a chyba i w całym bloku normalny, wielkonakładowy dziennik niezależny [...]. Takie gazety znamy dotąd tylko ze słyszenia, teraz zamierzamy je robić. W miarę możności już teraz, będąc jeszcze gazetą wyborczą i w niedalekiej przyszłości, gdy zostaniemy po prostu dziennikiem".

Pod względem redakcyjnym gazeta zapoczątkowała nową epokę w polskim dziennikarstwie. Teksty musiały być krótkie i treściwe. W porównaniu do tasiemcowych, nasączonych nie nadającą się do czytania nowomową artykułów zamieszczanych w oficjalnych gazetach, było to posunięcie nowatorskie. Informacje starano się zdobywać samodzielnie, z pierwszej ręki, serwis PAP wykorzystywano w ostateczności. Dziennikarze „Gazety” jako pierwsi sięgnęli do wzorów prasy zachodniej. Forma „Gazety Wyborczej” na polskim rynku prasowym była jedyna w swoim rodzaju. Adam Michnik przyznaje, że pismami, które wywarły wpływ na kształt gazety, były francuskie „El Paris” i „Liberation”.

Pierwsze po wojnie częściowo wolne (tzw. kontraktowe) wybory do Sejmu i wolne do Senatu odbyły się 4 czerwca 1989 roku. Głosowanie przebiegało w dwóch turach, przy 62 procentowej frekwencji wyborczej.

11 M. Frybes, P. Michel, Po komunizmie, 1996, s. 26-27.

12 A. Michnik, Cud Okragłego Stołu, ,Gazeta Wyborcza”, 6-7 lutego 1999, nr 31.

13 L. Dzierba, op. cit., s. 294. 
W pierwszej turze opozycja zdobyła niemal wszystkie 161 mandatów w Sejmie i 99 (na 100 możliwych) w Senacie.

W lipcu 1989 roku na łamach „Gazety Wyborczej”, drukującej jeszcze znaczek „Solidarności” w winiecie, Adam Michnik rzucił hasło: „Wasz prezydent - nasz premier". Przełamało to impas wokół obsady urzędu prezydenta. W dniu 19 lipca Zgromadzenie Narodowe przewaga jednego głosu wybrało prezydentem PRL Wojciecha Jaruzelskiego.

Przypomnijmy pokrótce, jak wyglądał polski system prasowy w okresie PRL-u, zwłaszcza w kontekście wszechpanującej cenzury wydawniczej.

„Cenzura” w Polsce została powołana dekretem 5 lipca 1946 roku, a w rzeczywistości była kontynuacją cenzury wojskowej czasu wojny, podporządkowanej Ministerstwu Bezpieczeństwa Publicznego. W dekrecie powołującym do istnienia Główny Urząd Kontroli Prasy, Publikacji i Widowisk (w skrócie GUK lub GUKPPiW) zapisano: „nadzór nad prasą, publikacjami, widowiskami; kontrolowanie rozpowszechniania wszelkiego rodzaju utworów za pomocą druku, obrazu i żywego słowa, mające na celu zapobieżenie: godzeniu w ustrój Państwa Polskiego, wprowadzaniu w błąd opinii publicznej przez podawanie wiadomości niezgodnych z rzeczywistością"14.

Nieprecyzyjne sformułowania dawały możliwość dowolnego interpretowania i stosowania przepisów. Paradoksalnie, także broniąc prawdziwości informacji, GUK dopuszczał się największej dezinformacji, nie tylko w publikacjach prasowych, lecz także naukowych, zwłaszcza z dziedzin humanistycznych: historii współczesnej, historii literatury, socjologii, filozofii. Wszystko można było podciągnąć pod zapis: „,naruszania dobrych obyczajów, godzenia w ustrój, naruszania międzynarodowych stosunków". Ten ostatni zapis przybrał w latach późniejszych wyraźniejszą formułę ,godzenia w sojusze"15.

W historii działania GUK wyraźnie zarysowuje się etap wstępny, przypadający na lata 1946-1950, kiedy prowadzono bardzo silną ideologizację środowisk twórczych. Działania cenzury były wielokierunkowe i prowadzone na różnych poziomach. Organizowano przeróżne konferencje, zjazdy, zebrania, na których działacze partyjni wygłaszali referaty

14 Dekret o utworzeniu GUKPPiW, Dziennik Ustaw 1946, Nr 34, poz. 210.

15 S. Żak, Cenzura wobec humanistyki w PRL, w: Granice wolności stowa, pod red. G. Miernika, Kielce-Warszawa 1999, s. 74. 
o obowiązkach nowej sztuki w nowej rzeczywistości ${ }^{16}$. W dziedzinie literatury i szeroko pojętej humanistyki ingerencje cenzury dotyczyły wszystkich tekstów krytycznych wobec ideologii marksistowskiej oraz wobec Związku Radzieckiego, wobec osób i zdarzeń, które skazano na wykreślenie z historii (np. zbrodnię katyńską jako czyn radziecki, układ Ribbentrop-Mołotow, którego skutkiem było wkroczenie Armii Czerwonej 17 września 1939 r. do Polski), książki, w których dopatrywano się treści antyrewolucyjnych. Powstała więc sytuacja dokładnie Orwellowska, działało „Ministerstwo Prawdy”, decydujące o tym, co społeczeństwo może wiedzieć, a czego nie może.

Ten model cenzury działał bezwzględnie w latach 1950-1955. Wtedy rozwinęła się bardzo kontrola polityczna wewnątrz instytucji naukowych, redakcjach czasopism, wydawnictwach, oddanych konstytucyjnie „ludowi pracującemu”, aby szybciej i sprawniej można było realizować „zasady wolności słowa, wypowiedzi, druku" ${ }^{\text {"17. }}$

Nasilenie lub osłabienie cenzury zależało od sprawujących władzę grup partyjnych - „oświeconych liberałów” lub „ciemniaków”. Koniec lat pięćdziesiątych i pierwsza połowa sześćdziesiątych odznaczały się względną łagodnością cenzury, która ukierunkowana była na pisma katolickie, typu „Tygodnik Powszechny”, „Więź”, „Znak” oraz na nazwiska autorów, którzy, korzystając z pewnego rozluźnienia, zaczęli pisywać w „Kulturze” paryskiej, a w krajowej podejmowali tematy nieco kompromitujące władzę ${ }^{18}$.

W czasach gomułkowskich kontrola była coraz bardziej uciążliwa, chociaż w 1956 r. Walny Zjazd ZLP wypowiedział się za zniesieniem wszelkich form cenzury i za wprowadzeniem ustawy prasowej przewidującej odpowiedzialność prawną autorów i redaktorów. Dnia 14 marca 1964 roku na ręce premiera Józefa Cyrankiewicza wysłano „List 34” następującej treści: „Ograniczenie papieru na druk książek i czasopism oraz zaostrzenie cenzury prasowej stwarza sytuację zagrażającą rozwojowi kultury narodowej. Niżej podpisani, uznając istnienie opinii publicznej, prawa do krytyki, swobodnej dyskusji i rzetelnej informacji za konieczny element postępu, domagają się zmiany polityki kulturalnej w duchu praw zagwarantowanych przez Konstytucję Państwa polskiego i zgodnych z do-

\footnotetext{
16 Ibidem, s. 75-76.

17 Ibidem, s. 80-81.

18 Ibidem, s. 81.
} 
brem narodu" $" 19$. Dokument ten podpisali, m.in. Paweł Jasienica, Stefan Kisielewski, Antoni Słonimski, Melchior Wańkowicz, Stanisław Cat-Mackiewicz, Maria Dąbrowska, Kazimierz Wyka, Jerzy Turowicz, Jerzy Andrzejewski, Władysław Tatarkiewicz, Adam Ważyk. List zdenerwował władze, które nałożyły na wielu restrykcje, m.in. zakaz współpracy z 12 sygnatariuszami „Listu” oraz zakaz wymieniania ich nazwisk w radiu i tygodnikach (m.in. Wańkowicza, Słonimskiego, Kisielewskiego).

Cenzura zaglądała do prywatnej korespondencji, zwłaszcza wysyłanej za granicę, o czym świadczył proces Melchiora Wańkowicza, oskarżonego o przesyłanie ,fałszywych informacji oczerniających stosunki w Polsce" (list wysłany był do córki w czerwcu 1964 r., przedrukowano go w „Antenie” w lipcu). Dnia 9 września pisarz został skazany na 3 lata więzienia (wyrok zmniejszono do półtora roku). Cenzurowanie środowisk twórczych: pisarzy, intelektualistów, naukowców, filmowców i przedstawicieli Kościoła (szczególnie kardynała Wyszyńskiego) doszło do granic wyraźnych represji, zwłaszcza gdy zaczęto posługiwać się wymiarem sprawiedliwości i organami ścigania. Szczyt tej represyjności osiągnięto w 1968 roku, kiedy to, w związku ze zdjęciem „Dziadów” ze sceny Teatru Narodowego, odbyło się zebranie nadzwyczajne Oddziału Warszawskiego ZLP, na którym Antoni Słonimski ostro atakował cenzurę ${ }^{20}$.

Wydarzenia marcowe, a w zasadzie cały rok 1968 stanowił szczególną datę w historii organów kontroli słowa w PRL. Grudzień 1970 r., podobnie jak Październik 1956 r., spowodował chwilowe osłabienie siły organów cenzorskich oraz zasięgu ich ingerencji w życie duchowe społeczeństwa. Nasilenie ich działań nastąpiło jednak już wkrótce - wraz z umocnieniem się nowego partyjnego kierownictwa, z Edwardem Gierkiem na czele. Rok 1976 wydaje się być, podobnie jak w czasach rządów ekipy gomułkowskiej rok 1968, znamiennym czasem przesilenia w dekadzie lat siedemdziesiątych. Wprowadzenie poprawek do konstytucji PRL, a następnie wydarzenia czerwcowe w Radomiu i Ursusie, zrodziły szereg istotnych zjawisk długotrwałego protestu społecznego. Ich konsekwencją były m.in. narodziny KOR-u oraz innych grup zorganizowanej opozycji, a także powstanie Wolnych Związków Zawodowych i wielu podziemnych tytułów nielegalnych gazetek ${ }^{21}$.

19 Ibidem, s. 82.

20 Ibidem, s. 83.

21 J. Adamowski, A. Koziel, Cenzura w PRL, w: Granice wolności ..., op. cit., s. 67. 
Czas niepokojów społecznych szczególnie mobilizował cenzurę, zwłaszcza - mocą rozporządzenia Rady Ministrów z dnia 22 kwietnia 1975 r. - uzbrojoną w nowe możliwości sprawowania nadzoru i kontroli nad wolnością słowa w PRL. Już paragraf 1 wspomnianego rozporządzenia wyraźnie akcentował, że ,rozpowszechnianie wszelkiego rodzaju druków, zapisów obrazu i słowa oraz każde publiczne wykonanie utworu $\mathrm{z}$ tekstem słownym albo utworu mimicznego w działalności artystycznej lub rozrywkowej, podlega nadzorowi kontroli Głównego Urzędu Kontroli Prasy, Publikacji i Widowisk [...] i wymaga zgody tego urzędu"22.

Pęczniała księga, tzw. zapisów cenzorskich, której rozmiary i absurdalność wielu tematycznych zakazów ujawniła dopiero ucieczka cenzora i opublikowanie Czarnej księgi cenzury $P R L^{23}$. Wstrząs u osób, które miały szansę zapoznania się z tymi dokumentami, był bezsporny. Znamienny w tym względzie wydaje się być szkic Michała Głowińskiego, w którym znajdujemy m.in. takie oto refleksje autora: „Piszę pod bezpośrednim wrażeniem lektury obszernego maszynopisu, udostępnionego publiczności przez KOR, zawierającego fragmenty zaleceń cenzorskich z ostatnich kilku lat. Jest to tekst zdumiewający i przerażający: złożony z urzędowych instrukcji, bez ogródek formułuje to, z czego skutkami obywatel PRL-u styka się na co dzień. [...] W Czarnej księdze cenzury PRL można znaleźć rozmaite zakazy, np.: »Nie dopuszczać do publikacji żadnych informacji: o wielkości spożycia kawy w skali rocznej i kraju celem uniemożliwienia ujawnienia wielkości reeksportu kawy, o sprzedaży mięsa przez Polskę do ZSRR, o przyznawaniu przez premiera rent specjalnych dla różnych osób; o bezpośrednim zagrożeniu życia i zdrowia ludzi spowodowanych przez przemysł i środki chemiczne stosowane w rolnictwie, o danych zbiorczych dotyczących ilości wypadków drogowych, pożarów i utonięć, o danych liczbowych obrazujących stan i wzrost alkoholizmu w skali całego kraju; o tym, że system komputerowy »Cyfronet « dla IBJ w Świerku został zakupiony w USA; na temat źródeł i sposobów finansowania ORMO, o życzeniach, jakie z okazji 60-lecia urodzin B. Piasecki otrzymał od kierownictwa Partii i Rządu«"24.

Okres kolejnego przesilenia społecznego, zapoczątkowanego strajkami w Świdniku, a potem na Wybrzeżu, po raz kolejny postawił na porządku dnia kluczową dla pokoleń opozycjonistów PRL sprawę swobo-

22 J. Balia, Prawo o cenzurze, Warszawa 1983, s. 221.

23 Czarna księga cenzury PRL, Wydawnictwo „Aneks”, Londyn 1977, s. 247.

24 K. Bachman, Nożyczki w głowie, ,Polityka” 15 kwietnia 2000, nr 16, s. 6. 
dy wypowiedzi, a więc także i przyszłych losów instytucji cenzury w Polsce. Ustawa „O kontroli publikacji i widowisk” z 31 lipca 1981 roku nie obowiązywała długo w swoim pierwotnym kształcie. Dekret o stanie wojennym z 12 grudnia 1981 r. w art. 17 rozszerzył bowiem zarówno zakres publikacji poddawanych cenzurze, jak i same podstawy ingerencji cenzorskich, poprzez wprowadzenie postanowienia, wedle którego można było odmówić zgody na rozpowszechnianie publikacji, jeśli miało to zagrażać interesom bezpieczeństwa lub obronności państwa ${ }^{25}$.

Dopiero podczas obrad „okragłego stołu” powstały podwaliny pod nową ustawę dotyczącą likwidacji cenzury. Ustawa z 11 kwietnia 1990 r. w art. 2 zniosła Główny Urząd Kontroli Publikacji i Widowisk oraz okręgowe urzędy kontroli publikacji i widowisk. Dała więc formalną podstawę prawną dla pełnej swobody środków masowego przekazu oraz zlikwidowała cenzurę istniejącą w rygorystycznej formie w Polsce w całym okresie powojennym ${ }^{26}$.

Ustawa z 11 kwietnia 1990 zniosła GUKKiW - jedną z bardziej ponurych i szkodliwych instytucji PRL. Urząd cenzurował każdy zadrukowany kawałek papieru, każdy metr taśmy. Ta instytucja, schowana w cieniu przy ul. Mysiej w Warszawie, działająca według tajnych partyjnych zaleceń, cenzurowała myśli i słowa, ale także kastrowała fakty. Przepuszczała peerelowska rzeczywistość przez filtr, zatrzymując wszystko to, co nie pasowało do obrazu szczęśliwego systemu szczęśliwych ludzi. Ale też cenzura dla wielu ludzi pióra, mikrofonu i kamery stanowiła alibi, była cichym współredaktorem. Wielu z nich cenzura uwalniała od odpowiedzialności. $\mathrm{Z}$ czasem wykształciła się surrealistyczna gra z cenzura - gra w aluzje, w puszczanie oka i pisanie między wierszami. I nagle zabrakło cenzora kata i zarazem - wspólnika. Przyszła wolność słowa, a wraz z nią wylała się fala informacji dotychczas oficjalnie skrywanych. Tak, jakbyśmy z dnia na dzień znaleźli się w innym kraju: pełnym morderstw na każdym kroku, biedy, zatrutego środowiska, narkomanii. Można już było pisać o wszystkim i szargać - prawie wszystkie świętości ${ }^{27}$.

Okres prasy PRL-owskiej zamknęły ustalenia „okrągłego stołu” (marzec 1989). Obie strony, partyjno-rządowa i solidarnościowa, uznały polski system komunikacji społecznej za przestarzały i nieodpowiedni.

25 Ibidem, s. 69-70.

26 A. Słomkowska, Zmiany $w$ mediach $w$ roku poprzedzajacym zniesienie cenzury, w: Granice wolności ..., op. cit., s. 101.

27 K. Bachman, op. cit., s. 3. 
Zgodziły się na zniesienie cenzury i pluralizm polityczny mediów. Uzgodniły rezygnację z systemu koncesyjnego na rzecz tzw. zgłoszenia sądowego, jako jedynego warunku wydawania tytułu prasowego. Ustalenia i wytyczne „okragłego stołu” zapoczątkowały proces transformacji środków masowego przekazu. Stopniowo zmieniało się ustawodawstwo. W maju 1989 r. Sejm uchwalił cztery ważne ustawy związane z prasą: o stosunku państwa do Kościoła katolickiego w PRL (z 17 V 1989) oraz o gwarancjach wolności sumienia i wyznania (z 17 V 1989), o zmianie ustawy o kontroli publikacji i widowisk (z 29 V 1989) i o zmianie ustawy „Prawo prasowe” (z $30 \mathrm{~V} 1989)^{28}$.

Wskutek postanowień „okragłego stołu” zaczęły lawinowo powstawać nowe pisma. Były one zróżnicowane pod względem częstotliwości, zasięgu, nakładu, objętości, programu i deklarowanej orientacji politycznej. Miały natomiast tę cechę wspólną, że były z reguły wydawane poza cenzurą. Ponadtysięczną listę nowo zarejestrowanych tytułów, między majem a grudniem 1989 roku, otwierała „Gazeta Wyborcza”, która jako dziennik opozycyjny, została wynegocjowana jeszcze podczas obrad „okragłego stołu”. Ujawniły się pisma opozycyjne lub wznowiły swoją działalność dzienniki i tygodniki solidarnościowe, które wychodziły oficjalnie przed stanem wojennym ${ }^{29}$.

W miejsce załamanych systemów prasowych, upadku i likwidacji tytułów poprzedniej formacji ustrojowej pojawiły się „,nowe” tytuły, a „stare” zostały przejęte przez nowe ugrupowania, partie, ośrodki i siły polityczne, w tym też pozaparlamentarne. W miejsce centralistycznego i monopolistycznego systemu komunikowania społecznego stworzono system zdecentralizowany, pluralistyczny. Ten kierunek przeobrażeń doprowadził do transformacji prasy, do istotnych zmian w ogólnokrajowej ofercie prasowej, do jej wyraźnego zróżnicowania i wzbogacenia - szczególnie w odniesieniu do prasy regionalnej czy lokalnej. Żywiołowa lawina nowych druków objęła kraj ${ }^{30}$.

Do roku 1989 wszystkie dzienniki były do siebie podobne, wręcz identyczne pod względem zawartości. Poza trzema dziennikami sportowymi,

28 A. Słomkowska, op. cit., s. 104.

29 E. Ciborska, Pięciolecie transformacji prasy postpezetpeerowskiej (1989-1994), w: Pięciolecie transformacji mediów (1989-1994), pod red. A. Słomkowskiej, t. XXV, Warszawa 1995, s. 191.

30 J. Jarowiecki, Studia nad prasa polska XIX i XX wieku, Kraków 1997, s. 203-204. 
wszystkie inne zachowywały - zgodnie z definicją prawną - ogólnoinformacyjny charakter i zamieszczały na swoich łamach wiadomości „o wszystkim i dla wszystkich"31.

Po 1989 roku rynek prasowy przestał być taki monotonny. Większość pism zmieniła format (w przypadku tygodników na A-4, w przypadku dzienników na A-3) i zmniejszyła liczbę kolumn. Ich zawartość stała się bardziej interesująca. Pojawiły się krótsze i bardziej urozmaicone informacje na kolumnach. Niejednokrotnie zamieszczano 5-7 materiałów na jednej kolumnie. Na czołówkach znalazły się treści dotąd przemilczane i zakazane. Zaczęto energicznie zabiegać o ogłoszenia ${ }^{32}$.

Po roku 1989 działalność w sferze mediów stała się rodzajem działalności gospodarczej. Każdy egzemplarz dziennika czy czasopisma, program radiowy czy telewizyjny stał się towarem, który produkuje się nie tyle w celach społecznie ważnych i potrzebnych, ile z chęci zysku. Widać to zwłaszcza w przypadku pism prywatnych oraz komercyjnych nadawców radiowych i telewizyjnych. O tym, że prasa - w szerokim znaczeniu stała się towarem, świadczy najlepiej fakt, że zarówno tytuły prasowe, jak i nadawcy komercyjni upadają, jeśli nie zdołają utrzymać się na rynku, czyli przynajmniej zarobić na utrzymanie, a także przynieść godziwy zysk właścicielowi ${ }^{33}$.

W okresie transformacji prasy pojawił się też problem obecności kapitału zagranicznego w polskich mediach. Do normalnych zjawisk na świecie zalicza się zjawisko inwestowania przez bogate kraje, a ściślej przez działające w nich koncerny i monopole prasowe - środków na obcych rynkach. Proces ten eufemistycznie określa się mianem internacjonalizacji. Polska znalazła się w sferze zainteresowania takich potentatów, jak Silvio Berlusconi, Axel C. Springer, H. Bauer, Reupert Murdoch, Robert Hersant czy Nicola Grauso ${ }^{34}$.

I wreszcie, nieodłącznym składnikiem przeobrażeń na polskim rynku prasowym stała się wymiana i fluktuacja kadr dziennikarskich. Rozpadły się dawne, liczne zespoły redakcyjne, nastąpiło zerwanie starych i tworzenie się nowych związków interpersonalnych. Nie chodzi tu tylko o zmiany osób pełniących funkcje redaktorów naczelnych, ich zastępców czy sekretarzy redakcji, ale o zmiany w zespołach czy wymianę prawie całych ze-

31 Ibidem, s. 205.

32 A. Słomkowska, op. cit., s. 104.

33 W. Sonczyk, Media w Polsce, Warszawa 1999, s. 17.

34 J. Jarowiecki, op. cit., s. 207. 
społów. Właściwie po raz pierwszy doszło w takiej skali do opuszczenia zawodu przez liczną grupę dziennikarzy. Jesienią 1989 r. pojawiły się pierwsze masowe zwolnienia $\mathrm{z}$ pracy: wtedy nie tylko padły pisma związane z dawnym systemem, ale 128 tytułów wśród oferty wydawniczej było deficytowych. Zostały one wraz z zespołami zlikwidowane w pierwszej kolejności. W czerwcu 1990 r. bez pracy znalazło się 422 dziennikarzy, we wrześniu było ich już 523. W samej Warszawie, do 15 września 1991 roku, pozbawiono pracy 850 dziennikarzy, z tego większość odeszła z zawodu ${ }^{35}$.

Niektórzy przyrównują sukces „Gazety Wyborczej” do amerykańskich mitów o fortunie od zera do milionera. To jednak nie był kaprys fortuny. Dziennik założyli ludzie z podziemia. Tam osiaggnęli sukces wydawniczy z „Tygodnikiem Mazowsze”, rozchodzącym się w nakładzie nawet 80 tysięcy egzemplarzy. 8 maja 1989 r. wydali pierwszy numer „Gazety Wyborczej” - osiem ascetycznych kolumn wypełnionych sylwetkami kandydatów do parlamentu z ramienia Komitetu Obywatelskiego. To był prawdziwy sukces, „Gazeta” rozeszła się błyskawicznie, ludzie odbijali ją na ksero i przekazywali innym. Nakład szybko wzrastał - od 150 tysięcy egzemplarzy doszedł do pół miliona. Zdarzały się numery drukowane w nakładzie 1 miliona. Dzisiaj średnia dzienna sprzedaż utrzymuje się na poziomie 450 tys. egzemplarzy, a przychody Agory (wydawcy „Gazety") ze sprzedaży za 1999 r. wyniosły 695 milionów złotych, o 26,2 procent więcej niż rok wcześniej" ${ }^{36}$.

Każdy egzemplarz „Gazety” składa się z przynajmniej trzech elementów: części ogólnopolskiej, przygotowywanej przez redakcję w Warszawie, dodatku regionalnego, przygotowywanego przez jedną z osiemnastu redakcji regionalnych (włączając redakcję dodatku warszawskiego „Gazety Stołecznej”) oraz dodatku tematycznego. W czwartki do „Gazety” dołączany jest Magazyn „Duży Format”, w piątki „Gazeta Telewizyjna”, a w soboty „Wysokie Obcasy”. Do „Gazety” dołączane są także okazjonalne wkładki kolorowe, płyty muzyczne z okazji świąt, a nawet garść sianka na Boże Narodzenie. W 1997 r. „Wyborcza” miała średnio 100 stron objętości, w Warszawie często przekraczając 200. Obok objętości, cechą wyróżniającą „Gazetę” na krajowym rynku, jest sposób łączenia wiadomości krajowych i lokalnych. Realizacja tej kon-

35 Ibidem, s. 208.

36 P. Pytlakowski, Milionerzy z Wyborczej, „Polityka” 15 lipca 2000. s. 22. 
cepcji jest możliwa dzięki opanowaniu skomplikowanego procesu redakcji i druku ${ }^{37}$.

„Gazeta Wyborcza” jako pierwsza polska gazeta o zasięgu ogólnopolskim rozpoczęła penetrację pozacentralnych regionów, poprzez tworzenie lokalnych oddziałów i dodatków. Pierwszy taki dodatek powstał w Katowicach. Obecnie jest ich 18 . Obejmują w przybliżeniu obszary dawnych „gierkowskich” województw. Każdy dodatek regionalny „Gazety Wyborczej" jest zarejestrowany jako odrębny tytuł prasowy, redagowany przez lokalnych dziennikarzy. Każda lokalna redakcja musi wykazywać się też pewną finansową samodzielnością, czerpaną głównie z reklam na lokalnych rynkach. Mutowane są też pierwsze „ogólnopolskie” strony rozprowadzanej w regionach „Gazety Wyborczej”, stwarzając znakomite psychologiczne wrażenie, że Białystok czy Poznań ma własną „Gazetę Wyborczą"38.

Na mocy umowy z dnia 22 listopada 1996 r. Agora posiada licencję na przedrukowywanie artykułów i grafiki, a także na korzystanie z innych informacji publikowanych w ,The Wall Street Journal Europe” oraz używanie znaku towarowego „The Wall Street Journal” i „The Wall Street Journal Europe”, należącego do Dow Jones \& Company, Inc. ${ }^{39}$

„Gazeta Wyborcza” od pierwszych numerów proponowała rzeczy, które były nie do pomyślenia w skostniałej prasie. Wprowadzono TOP Telefoniczną Opinię Publiczną, która zachęciła czytelników do aktywności. Każdego dnia redakcja rejestruje dziesiątki telefonów, z których dziennikarze wybierają i publikują najciekawsze. Wprowadzono też rubryki: „Cytat dnia” i „Liczba dnia”, skrótowo opisujące zachodzące zmiany w świecie. Od kilku lat w niektórych regionach, w tym także w Warszawie, każdego dnia ogłoszenia drobne zamieszczane są w osobnym dodatku konsumenckim „Supermarket”.

Magazyn dołączany do „Gazety” w czwartki (ostatnio w poniedziałki) zawiera reportaże, artykuły i eseje na temat sztuki, nauki, historii i literatury oraz stałe rubryki poświęcone modzie, urodzie, motoryzacji i kuchni. Dzięki połączeniu poważnych i lekkich tematów, Magazyn jest czytany zarówno przez dawną inteligencję, jak i przedstawicieli nowej klasy średniej. $\mathrm{Z}$ tego powodu stał się cenionym narzędziem ogłoszeniodawców.

37 Prospekt Emisyjny Agory S.A., Warszawa 11 maja 1998, s. 71.

38 W. Darski, Agora - imperium atakuje, „Tygodnik Solidarność” 3 lipca 1998, s. 20 .

39 Prospekt ..., s. 90. 
W odróżnieniu od innych produktów „Gazety Wyborczej”, „Duży Format” drukowany jest w technice „heat set”, która umożliwia uzyskanie wysokiej jakości kolorowego druku i w konsekwencji wyższych stawek w cenniku ogłoszeń ${ }^{40}$.

„Gazeta Telewizyjna” ma zasięg ogólnopolski, jednak niektóre strony są mutowane regionalnie w zależności od programów regionalnych telewizji.

Z kolei sobotni magazyn dla kobiet - „Wysokie Obcasy” jest drukowany w tej samej technologii co „Duży Format”, ale w mniejszym formacie. Kierownictwo Agory nie ukrywa, że „Wysokimi Obcasami” chce odebrać część reklamodawców pismom kobiecym.

„Gazeta Wyborcza” zaczęła też pełnić rolę podręcznego poradnika w różnych dziedzinach, mnożąc rozmaite dodatki fachowe. Dodatki tematyczne dzielą się na ogólnopolskie oraz regionalne. Każdy dzień tygodnia ma swój temat: praca w poniedziałek, komputery i biuro, a także komunikaty firm i urzędów we wtorek, dom i budownictwo oraz nieruchomości w środę, motoryzacja w czwartek, sport i informator kulturalny w piątek oraz turystyka w sobotę.

W pierwszych latach istnienia „Gazety” wszystkie teksty były przepisywane, jak na maszynie, na linotypach, które odlewały je w ołowiane wiersze. Dziś proces produkcyjny „Gazety” jest w pełni zautomatyzowany. Teksty pisane na komputerach przechodzą z komputera na komputer, gdzie poddawane są obróbce redakcyjnej i graficznej, a z ostatniego wychodzi gotowa strona, która wędruje do nowoczesnej drukarni offsetowej. Dzięki tej technice można nadać stronie dowolny wygląd, zamieszczać duże zdjęcia i kolorowe infografiki ${ }^{41}$. Proces redagowania i druku „Gazety” wymaga doskonałej koordynacji działań centrali w Warszawie i oddziałów oraz ścisłej współpracy oddziałów z drukarniami w Warszawie, Tychach i Pile wraz z drukarniami zewnętrznymi.

Dziś niewiele już osób pamięta, jak wyglądała pierwsza winieta „Gazety Wyborczej”. Trudno wyobrazić sobie, że dziesięć lat temu „Gazeta” drukowana była na szorstkim, rozmazującym się papierze. Była czarno-biała i liczyła zaledwie kilka stron. Dzisiaj ma blisko sto stron i można ją kupić w każdym kiosku - nawet w najmniejszej wiosce.

40 Prospekt ..., s. 72.

41 Witajcie $w$ nowych stronach, „Gazeta Wyborcza” 9 maja 1995, s. 1. 
Pomimo konkurencji ze strony innych dzienników, „Gazeta” utrzymała w ostatnich latach stosunkowo stabilną liczbę sprzedawanych dziennie egzemplarzy, przy czym średnia kwartalna sprzedaż wynosiła od 381000 do $455000 \mathrm{w}$ latach 1994-1997 $7^{42}$.

Liczba niesprzedanych egzemplarzy (zwrotów) „Gazety” sięga dwudziestu procent nakładu, co, biorąc pod uwagę wysoką liczbę sprzedawanych egzemplarzy, jest korzystnym wynikiem na tle innych gazet ogólnokrajowych. Zarząd Agory uważa, że niższy poziom zwrotów świadczyłby o tym, że liczba egzemplarzy dostarczanych do punktów sprzedaży detalicznej jest zbyt niska w stosunku do potrzeb na danym terenie. $\mathrm{Z}$ tego powodu Agora prowadzi stałe badania nasycenia rynku, tak aby zwroty nigdy nie były zerowe ${ }^{43}$.

Zdaniem Jana Miodka, „Gazeta Wyborcza” ma najciekawsze i najdowcipniejsze nagłówki, a każdy numer przynosi po kilka przykładów zasługujących na filologiczną analizę. Kiedy szefem Telewizyjnej Agencji Informacyjnej (TAI) został Jarosław Gugała, dziennikarze „Wyborczej” skomentowali tę nominację grą słów: „Gugało wi-TAI”. Zdaniem Miodka, „zabawa słowami, ich brzmieniowymi podobieństwami jest w ogóle najczęstszym środkiem stylistycznym wykorzystywanym w nagłówkach”44. Natomiast zdaniem prof. Jacka Sobczaka, tytuły „Gazety Wyborczej" są często na granicy prawa.

Oprócz tego, że „Gazeta Wyborcza” jest... gazetą, jest także biznesem. O losie „Gazety” decyduje czytelnik, który postanawia codziennie ją kupować, uszczuplając budżet domowy. Kiedyś było inaczej - o istnieniu gazety decydował Komitet Centralny PZPR albo życzliwy donator dotacji na działalność opozycyjną.

Zmieniły się czasy. Dzisiaj gazeta musi zdobyć czytelnika. Musi przekonać go, że warto w nią inwestować, że warto ją kupować i czytać. Zdaniem Adama Michnika, wydawca gazety musi rozumieć i respektować prawa rynku, ale zarazem - zdobywając czytelnika - musi wiedzieć, po co chce go zdobyć ${ }^{45}$.

W 2000. numerze redakcja „Gazety” opublikowała ankietę o samej sobie. Obszerny kwestionariusz wypełniły aż 4402 osoby. Dwie trzecie an-

42 Prospekt ..., s. 78.

43 Prospekt ..., s. 76.

44 J. Miodek, Nagłówki „,Gazety Wyborczej”, „Słowo Polskie” 22-23 sierpnia 1992 , s. 5 .

45 A. Michnik, „Gazeta” ..., s. 15. 
kietowanych podkreślało, że „Gazeta” jest „bogata, że jest w niej dużo do czytania”. W ogóle najczęściej chwalono zawartość informacyjną. Ponad połowa uznała, że „Gazeta” jest żywa, zaś blisko połowa, że mądra ${ }^{46}$. Równo połowa ankietowanych, na pytanie, dlaczego czyta „Gazetę”, wybrała odpowiedź: „Bo to jest moja gazeta”. Dowiedzieliśmy się też, że czytelnicy wybierali średnio po jednej wadzie i ponad trzy zalety „Gazety”. Najczęstszym grzechem „Wyborczej”, zdaniem połowy badanych, jest „tendencyjność albo „zacietrzewienie”. Czytelnicy, którzy pisali o tej wadzie, zarzucali „Gazecie” zaślepienie swoimi poglądami. Polemizowałoby z nimi 38\% uczestników ankiety, którzy sądzą, że „Wyborcza” jest gazetą obiektywną.

Ankiety nadesłane przez kilka tysięcy respondentów, a także comiesięczne analizy rynku czytelniczego przybliżyły „Gazecie” wyobrażenie o grupie jej czytelników. Kim są ludzie, którzy czytają „Wyborczą”? Kto w ogóle czyta prasę w Polsce, jaką i czego w niej szuka?

Wśród wszystkich czytelników „Gazety” tych najstarszych jest jednak tylko $25 \%$, czyli mniej, niż w całym społeczeństwie. Najmłodsi uczestnicy ankiety mieli po 12 lat. Pisali, że w „Gazecie” mogą znaleźć artykuły przydatne do odrabiania lekcji.

„Gazeta”, jak każdy poważny dziennik, jest - w odróżnieniu od popularnych, sensacyjnych czy skandalizujących pism - czytana przez ludzi lepiej wykształconych. Aż 57\% respondentów to ludzie po studiach. Ludzi z wykształceniem podstawowym lub zawodowym było ledwie $6 \%$ (wśród nieregularnych czytelników jest ich $30 \%$, a w całym społeczeństwie blisko dwa razy więcej).

W całym społeczeństwie mężczyzn jest nieco mniej niż kobiet. Za to wśród nieregularnych czytelników „Gazety” panów jest 54\%, a wśród czytelników regularnych aż $60 \%$. Wśród tych, którzy odpowiedzieli na ankietę - jeszcze więcej - $67 \%{ }^{47}$.

Badania czytelnictwa „Gazety” i nadesłane ankiety są dowodem, że „Wyborcza” wypełnia ważną przestrzeń komunikacyjno-psychologiczną, stała się układem odniesienia dla wielu jej odbiorców. Często konfrontacje i spory z tym, co pisała, pozwalały adwersarzom znaleźć swoje własne myśli i odczucia. Zawsze wywoływała i wywołuje gorące reakcje: modne jest wybrzydzanie na nią, narzekanie, wyśmiewanie, łapanie błędów. Nie

46 Ibidem, s. 15.

47 P. Pacewicz, G. Skibicka, Cała prawda o „Wyborczej”, „Gazeta Wyborcza”, 8 maja 1996, s. 12. 
brakuje też namiętnej nienawiści i pogardy u myślących inaczej. „Gazeta Wybiórcza” to może najłagodniejszy epitet; do mocniejszych należy „gazeta polskojęzyczna”, którego rozbiór logiczny i semantyczny daje się łatwo przeprowadzić. Co jak co, ale w geografii ideowej III RP miejsce „Gazety Wyborczej” jest łatwe do zlokalizowania, tyleż dzięki jej wrogom, co przyjaciołom ${ }^{48}$.

Trudno będzie kiedykolwiek odpowiedzieć na pytanie, co konkretnie zadecydowało o sukcesie „Gazety Wyborczej”. Wszystkie wymienione w tym artykule czynniki miały w tym zwycięstwie swój udział.

\section{Summary}

Since the first issue of „Gazeta Wyborcza” was published, on Monday $8^{\text {th }}$ May 1989, it has become a true phenomenon on the Polish press market. After two months from the first publication it became very popular due to the slogan created by A. Michnik „your President - our Prime Minister”. „Gazeta Wyborcza” as the first newspaper published in democratic Poland became more than the biggest source of information as it also had a great influence on shaping of the political opinions of many Poles. It also supported the "Solidarity" movement and the new government. „Gazeta Wyborcza” was the first newspaper in democratic Poland whereone could find uncensored articles addressed to people, respecting their expectations and the right to information free from censorship. There is no doubt that "Gazeta Wyborcza” created by Adam Michnik, editor-in-chief, has currently got as many readers as critics but it is impossible to remain unaffected by its content.

48 Redakcja „Polityki”, Wybory „,Wyborczej”, „Polityka”, 8 maja 1999, s. 30. 